\section{Update on and Review of the Incompatibility $(S$-) Genotypes of Apple Cultivars}

\author{
Wim Broothaerts ${ }^{1}$ \\ Better3Fruit N.V., Willem de Croylaan 42, B-3001 Leuven, Belgium
Ilse Van Nerum and Johan Keulemans
Fruitteeltcentrum K.U.Leuven, Willem de Croylaan 42, B-3001 Leuven, Belgium

Additional index words. Malus $\times$ domestica, allele-specific PCR, S-allele, self-incompatibility, pollination

\begin{abstract}
Apple cultivars display a self-incompatibility system that restricts self-fertilization and fertilization between cultivars bearing identical $S$-alleles. There has been considerable progress in identification of $\mathrm{S}$-alleles in apple in recent years and methods are now available for the accurate $S$-genotyping of cultivars. Following a recently revised numerical identification system for apple $S$-alleles, we present the first extensive compilation of apple cultivars with their $\mathrm{S}$-genotypes. This list contains data from our own investigations using S-allele-specific PCR methodology, including a number of new data, as well as published data from various other sources. Eighteen different $\mathrm{S}$-alleles are discriminated, which allowed the determination of the S-genotypes for 150 diploid or triploid European,American, and Japanese cultivars. Many of these cultivars are cultivated worldwide for their fruit. Also included are a number of old, obsolete cultivars and a few nondomestic genotypes. We observed a wide variation in the frequency of $\mathrm{S}$-alleles in the apple germplasm. Three $S$-alleles $\left(S_{2}, S_{3}\right.$, and $\left.S_{9}\right)$ are very common in the cultivars evaluated, presumably as a result of the widespread use of the same breeding parents, and seven alleles are very rare $\left(S_{4}\right.$, $\left.S_{6}, S_{8}, S_{16}, S_{22}, S_{23}, S_{26}\right)$.
\end{abstract}

The production of apples generally requires that pollen be transferred from one cultivar (the pollinizer) to the stigmas of the cultivar to be pollinated (main fruit-bearing cultivar). There, the pollen grains germinate and produce a tube that enters the stigmatic tissue and elongates through the style towards the ovules where fertilization takes place. During their growth, the pollen tubes are attacked by abundant cytotoxic proteins that enter their cytoplasm. Lethal attack is avoided through the expression of specific inhibitors of these proteins, allowing pollen tube growth to proceed (Golz et al., 2001). This mechanism appears to be the way the gametophytic self-incompatibility system operates. The style-encoded toxic proteins are the products of the $S$-gene, which are the SRNases. The pollen-expressed inhibitors of the pollen-S gene have not been identified. Both genes are part of the polymorphic S-locus. If the alleles of the S-gene and of pollen-S match, i.e. they have the same S-locus specificity, an incompatibility reaction is elicited, which is manifested by the arrest of pollen tube growth somewhere in the style. In such cases, the inhibitors produced in the pollen tube were apparently unable to inactivate the stylar S-RNases.

Received for publication 2 Jan. 2003. Accepted for publication 23 June 2003.

${ }^{1}$ Current address: Center for the Application of Molecular Biology to International Agriculture (CAMBIA), GPO Box 3200, Canberra, ACT 2601, Australia; email Wim.Broothaerts@ Cambia.org.
Several alleles of the S-gene in apple have been identified and their nucleotide sequences have been determined (Broothaerts, 2003). Based on the diversity of nucleotide sequences encoding the S-RNase family members, a method has been developed using allele-specific PCR primers to selectively amplify and identify particular S-alleles (Janssens et al., 1995). This method was recently re-examined, modified, and extended for the identification of additional alleles (Broothaerts, 2003). At the same time, the annotation of S-alleles was revised because of the occurrence of more than one symbol for some $\mathrm{S}$-alleles in the literature. The new numbering introduced $\mathrm{S}_{16}, \mathrm{~S}_{19}, \mathrm{~S}_{22}$, and $S_{23}$, as a replacement of the former $S_{27 a}$ (in 'Baskatong'), $S_{28} / S d$ (in 'Delicious'), $S_{27 \mathrm{~b}}^{27 \mathrm{a}}$ (in 'Alkmene'), and the erroneously assigned " $S_{10}$ " (in 'Granny Smith'), respectively. Following further investigations (S. Matsumoto, personal communication), it appeared that $\mathrm{S}_{19}$ is a rare, but distinct allele, and hence the proposed merger with $\mathrm{S}_{28}$ as suggested by Broothaerts (2003) should be corrected. In this paper, we therefore refer to $\mathrm{S}_{28}$ for the S-allele of Delicious and keep $S_{19}$ for the $S$-allele assigned to Bohnapfel (Boškovi and Tobutt, 1999) and sequenced by Matsumoto (unpublished data). Allele-specific analysis conditions have been described for the detection of $15 \mathrm{~S}$-alleles that operate in the domestic apple germplasm (Broothaerts, 2003). An additional allele, $\mathrm{S}_{25}$, a PCR/digestion method was suggested for its detection (Kitahara and Matsumoto, 2002). The sequences of a few other alleles have not been has recently been cloned and sequenced and determined but their presumed gene products were detected by RNase zymogram analysis (Boškovic and Tobutt, 1999). However, so far all of the RNases for which the corresponding gene sequences are unknown, except $\mathrm{S}_{6}$ and $\mathrm{S}_{8}$, have been detected only in a single, generally obsolete cultivar. For some of them, evidence has been reported showing that they correspond to known S-alleles, which, if confirmed, would exclude their existence as distinct S-alleles (Broothaerts, 2003; Matsumoto et al., 2003). Several other new $S$-alleles that were proposed by Tobutt's group may, therefore, also appear to be false if adequately examined. We have, therefore, decided to limit our investigations to the $16 \mathrm{~S}$-alleles that are characterized at the nucleotide sequence level. Additionally, the $\mathrm{S}_{6}$ and $\mathrm{S}_{8}$-allele were included in our study, as these are characterized both phenotypically and at the protein level. While $S_{6}$ has been found in two uncommon, local Swiss cultivars, $\mathrm{S}_{8}$ has been discovered in a few more common cultivars (Kobel et al, 1939; Boškovi and Tobutt, 1999).

Broothaerts (2003) validated the revised conditions for S-allele analysis by analysis of a collection of old apple cultivars that were genotyped by Kobel et al. (1939) through extensive cross-pollination studies. Here we have applied the same methodology to assay the Sallele genotypes of a number of generally more common European, American and Japanese apple cultivars. Our results were complemented by the inclusion of data from various other sources, resulting in an extensive overview of the current knowledge of the S-genotypes of primarily domestic apple cultivars.

\section{Experimental Protocols}

The plant material used was primarily derived from the extensive gene bank of the Fruitteeltcentrum K.U.Leuven, with a few cultivars from the Brogdale (UK) collection.

Unless otherwise indicated, the methods used in our work were described in Broothaerts (2003). Genomic DNA was isolated from leaves of various cultivars, amplified with allele-specific primers by PCR, and the fragments separated by agarose gel electrophoresis. For the unique identification of a few S-alleles $\left(\mathrm{S}_{4}\right.$, $\mathrm{S}_{16}, \mathrm{~S}_{20}, \mathrm{~S}_{22}$ ), allele-specific restriction enzymes were employed to digest the amplified products before gel analysis. Of the $18 \mathrm{~S}$-alleles evaluated here, only $\mathrm{S}_{6}$ and $\mathrm{S}_{8}$ were not determined by allele-specific PCR because their nucleotide sequences are unknown. The presence of these two alleles was inferred from the analysis of their stylar RNase patterns by Boškovic and Tobutt (1999). Also we did not determine the presence of the $\mathrm{S}_{25}$-allele, which only recently has been sequenced.

\section{Results}

We have assayed a large number of apple cultivars by allele-specific PCR to evaluate cross-incompatibility relationships in the apple germplasm. Complementing our previous report on the S-genotypes of a collection of old cultivars with known incompatibility 
Table 1. S-allele genotypes of apple cultivars.

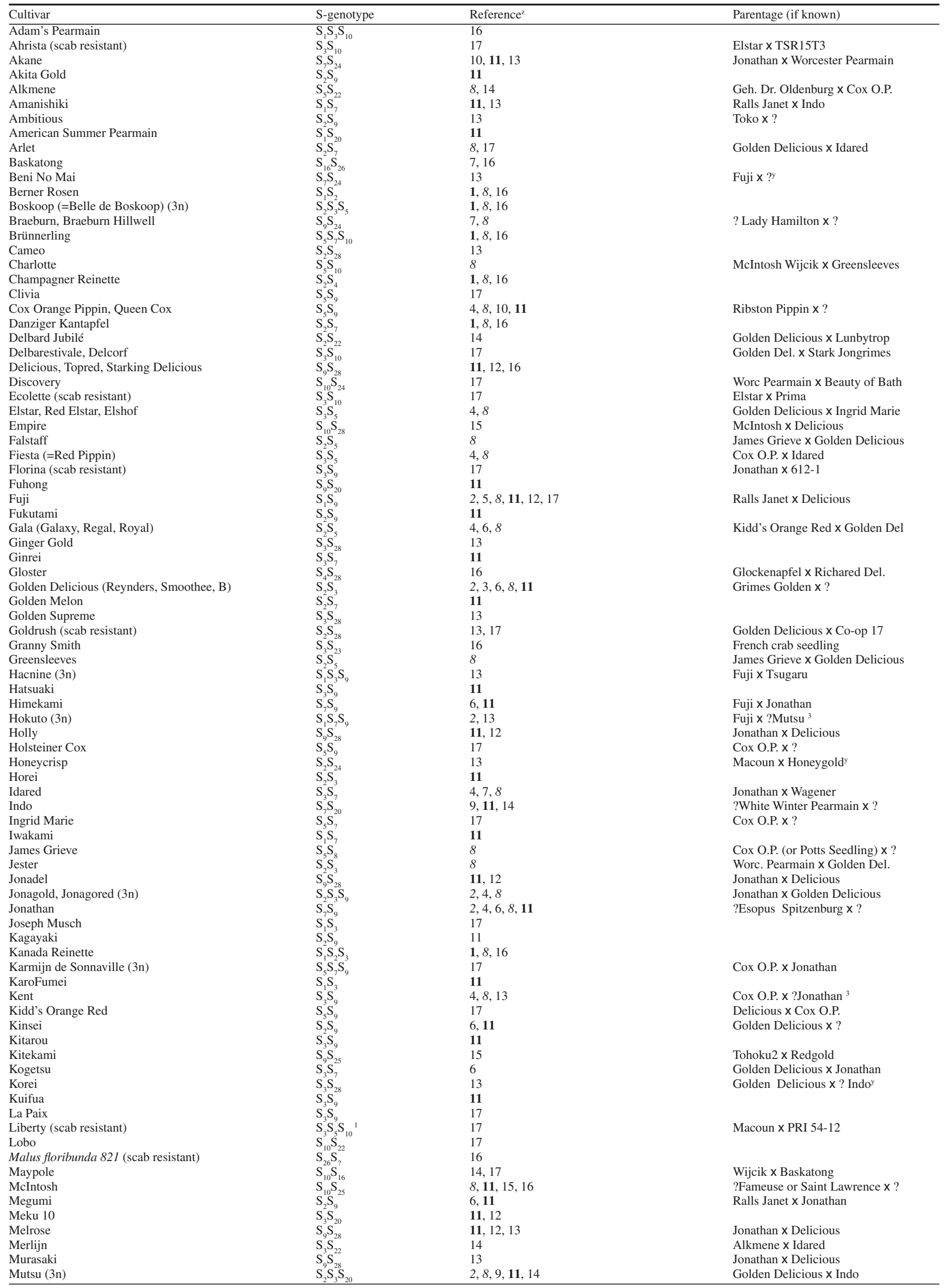


phenotypes, we report here on the analysis of another group of apple cultivars, comprising diploid and triploid cultivars of various origin (Table 1). Of the 39 new entries examined, 28 represent cultivars that have not been shown before. For the remaining eleven entries, our results confirmed those reported earlier.

Over the time period 1995-2003, our lab has reported the S-genotypes of a total of 73 cultivars using various versions of the S-allele-specific PCR methodology that is now commonly used for the detection of the

Table 1 (continued). S-allele genotypes of apple cultivars.

\begin{tabular}{|c|c|c|c|}
\hline Cultivar & S-genotype & Reference $^{z}$ & Parentage (if known) \\
\hline Natsumidori & $\mathrm{S}_{3} \mathrm{~S}_{9}$ & 11 & \\
\hline Narihokou & $\mathrm{S} \mathrm{S}_{2}$ & 11 & \\
\hline Nebuta & $\mathrm{S}_{3} \mathrm{~S}_{9}^{2}$ & 13 & Kitakami x Tsugaru \\
\hline Northern Spy & $\mathrm{S}_{1}^{3} \mathrm{~S}_{3}^{9}$ & $\mathbf{1 1}, 13,17$ & \\
\hline North Queen & $\mathrm{S}_{1} \mathrm{~S}_{3}^{3}$ & 13 & Fuji $\times$ Tsugaru \\
\hline Oberrieder Glanzreinette & $\mathrm{S}_{3} \mathrm{~S}_{6}{ }_{6}$ & $\mathbf{1}, 8$ & \\
\hline Oetwiler & $\mathrm{S}_{3}^{3} \mathrm{~S}_{6}$ & $\mathbf{1}, 8,17$ & \\
\hline Ontario & $\mathrm{S}_{1} \mathrm{~S}_{8}$ & $\mathbf{1}, 8$ & Wagener $\mathrm{x}$ Northern Spy \\
\hline Orei & $\mathrm{S}_{2} \mathrm{~S}_{28}$ & $\mathbf{1 1}, 12,13$ & Golden Delicious x Delicious \\
\hline Orin & $\mathrm{S}_{2}^{2} \mathrm{~S}_{7}$ & 6,11 & Golden Delicious x Indo \\
\hline Qingguan & $\mathrm{S}_{2}^{2} \mathrm{~S}_{20}^{\prime}$ & 11 & \\
\hline Pink Lady & $\mathrm{S}_{2}^{2} \mathrm{~S}_{23}^{20}$ & 17 & Golden Del. x Lady Williams \\
\hline Prima (scab resistant) & $\mathrm{S}_{2}^{2} \mathrm{~S}_{10}^{23}$ & 8,17 & PRI 14-510 x N.J. 123249 \\
\hline Princess & $\mathrm{S}_{3}^{2} \mathrm{~S}_{7}$ & 11 & \\
\hline Priscilla (scab resistant) & $\mathrm{S}_{3}^{3} \mathrm{~S}_{9}^{\prime}$ & 17 & Starking Delicious x PRI 610-2 \\
\hline Radoux & $\mathrm{S}_{+928}^{3} \mathrm{~S}_{?}$ & 17 & \\
\hline Ralls Janet & $\mathrm{S}_{1} \mathrm{~S}_{2}$ & $\mathbf{1 1}, 13,15,17$ & \\
\hline Redfree (scab resistant) & $\mathrm{S}_{3} \mathrm{~S}_{7}^{2}$ & 13 & Raritan x PRI 1018-101 \\
\hline Redgold & $\mathrm{S}_{2} \mathrm{~S}_{9}$ & 6 & \\
\hline Reine de Reinettes (=King of the Pippins) & $\mathrm{S}_{1}^{2} \mathrm{~S}_{3}$ & $\mathbf{1}, 8,16$ & ?Sturmer Pippin x Ribston Pip. \\
\hline Rewena (scab resistant) & $\mathrm{S}_{3} \mathrm{~S}_{9}^{3}$ & 17 & \\
\hline Rome Beauty (=Morgenduft, Imperatore) & $\mathrm{S}_{20}^{3} \mathrm{~S}_{24}^{9}$ & 17 & \\
\hline Rubin & $\mathrm{S}_{2} \mathrm{~S}_{3}{ }_{3}^{24}$ & 17 & \\
\hline Rubinette, Rafzubin & $\mathrm{S}_{3}^{2} \mathrm{~S}_{5}^{3}$ & 17 & Golden Delicious x Cox O.P. \\
\hline Sampion & $\mathrm{S}_{3} \mathrm{~S}_{5}$ & 17 & Golden Delicious x Cox O.P. \\
\hline Sansa & $\mathrm{S}_{5}^{3} \mathrm{~S}_{7}^{3}$ & 6 & Gala x Akane \\
\hline Sauergrauech, Rote Sauergrauech & $\mathrm{S}_{1} \mathrm{~S}_{3}$ & $\mathbf{1}, 8,16$ & \\
\hline Sayaka & $\mathrm{S}_{3} \mathrm{~S}_{9}$ & 6 & Jonathan x Sekai-ichi \\
\hline Sekai-ichi & $\mathrm{S}_{3}^{3} \mathrm{~S}_{9}$ & 6,11 & Delicious x Golden Delicious \\
\hline Sekihikari & $\mathrm{S}_{20}^{3} \mathrm{~S}_{2}$ & 11 & Toko $x$ Fuji \\
\hline Senshu & $\mathrm{S}_{1}^{20} \mathrm{~S}_{7}^{2}$ & $9, \mathbf{1 1}, 13$ & \\
\hline Shinkou & $\mathrm{S}_{1} \mathrm{~S}_{9}^{\prime}$ & 11 & \\
\hline Shinsei & $\mathrm{S}_{3} \mathrm{~S}_{5}$ & 13 & Golden Del. x Early McIntosh \\
\hline Shinano Red & $\mathrm{S}_{3}^{3} \mathrm{~S}_{10}$ & 15 & Tsugaru $x$ Vista Bella \\
\hline Shizuka & $\mathrm{S}_{2}^{3} \mathrm{~S}_{3} \mathrm{~S}_{20}$ & 11 & \\
\hline Spartan & $\mathrm{S}_{9} \mathrm{~S}_{10}{ }^{20}$ & 17 & McIntosh $\mathrm{x}$ ? \\
\hline Spencer & $\mathrm{S}_{2} \mathrm{~S}_{10}$ & 15 & McIntosh x Golden Delicious \\
\hline Spigold (3n) & $\mathrm{S}_{1}^{2} \mathrm{~S}_{2} \mathrm{~S}_{3}$ & 13 & Red Spy x Golden Delicious \\
\hline Spijon & $\mathrm{S}_{3} \mathrm{~S}_{7}^{2}$ & 13 & Red Spy x Monroe \\
\hline Stäfner Rosen & $\mathrm{S}_{3}^{3} \mathrm{~S}_{7}^{7} \mathrm{~S}_{8}$ & $\mathbf{1}, 8$ & \\
\hline Summerred & $\mathrm{S}_{2} \mathrm{~S}_{9}$ & 4,8 & (McIntosh x Golden Del. $)$ ? \\
\hline Telamon & $\mathrm{S}_{3}^{2} \mathrm{~S}_{10}$ & 14,17 & Wijcik x Golden Delicious \\
\hline Tohoku2 & $\mathrm{S}_{24}^{3} \mathrm{~S}_{25}$ & 15 & McIntosh $\mathrm{x}$ Worcester Pearmain \\
\hline Tohoku4 & $\mathrm{S}_{9} \mathrm{~S}_{24}^{25}$ & 13 & \\
\hline Tohoku5 & $\mathrm{S}_{2} \mathrm{~S}_{7}^{24}$ & 11 & \\
\hline Tohoku6 & $\mathrm{S}_{2}^{2} \mathrm{~S}_{9}$ & 11 & \\
\hline Tohoku10 & $\mathrm{S}_{2}^{2} \mathrm{~S}_{9}$ & 11 & \\
\hline Topaz (scab resistant) & $\mathrm{S}_{2}^{2} \mathrm{~S}_{5}$ & 17 & Rubin $\times$ Vanda \\
\hline Toyo & $\mathrm{S}_{5}^{2} \mathrm{~S}_{28}^{5}$ & 13 & Delicious $\mathrm{x}$ ? \\
\hline Trajan & $\mathrm{S}_{2} \mathrm{~S}_{25}^{28}$ & 8 & \\
\hline Transparent von Croncels & $\mathrm{S}_{2}^{2} \mathrm{~S}_{3}$ & $\mathbf{1}, 8,16$ & \\
\hline Trezeke Meyers & $\mathrm{S}_{7}^{2} \mathrm{~S}_{20}$ & 17 & \\
\hline Tsugaru & $\mathrm{S}_{3} \mathrm{~S}_{7}{ }_{7}$ & $\mathbf{1 1}, 15$ & Golden Delicious $\mathbf{x}$ ? \\
\hline Tuscan & $\mathrm{S}_{5}^{3} \mathrm{~S}_{10}$ & 8 & Wijcik x Greensleeves \\
\hline Tydeman's Early Worcester & $\mathrm{S}_{24} \mathrm{~S}_{25}$ & 8,17 & McIntosh x Worcester Pearmain \\
\hline Umezawa & $\mathrm{S}_{1} \mathrm{~S}_{3}{ }_{3}^{25}$ & 11 & \\
\hline Vanda & $\mathrm{S}_{5} \mathrm{~S}_{7}^{3}$ & 17 & Jolana $x$ Lord Lambourne \\
\hline Vista Bella & $\mathrm{S}_{10} \mathrm{~S}_{24}$ & 15 & \\
\hline White Transparent & $\mathrm{S}_{1} \mathrm{~S}_{5}$ & $\mathbf{1}, 8,16$ & \\
\hline Wellington Reinette (Dumelow's Seedl.) & $\mathrm{S}_{8} \mathrm{~S}_{9}$ & $\mathbf{1}, 8$ & \\
\hline Wijcik & $\mathrm{S}_{10}^{8} \mathrm{~S}_{25}$ & 17 & Mutant of McIntosh \\
\hline Winter Banana & $\mathrm{S}_{3} \mathrm{~S}_{5}{ }_{5}^{23}$ & 17 & \\
\hline Worcester Pearmain & $\mathrm{S}_{2} \mathrm{~S}_{24}$ & $\mathbf{1 1}, 12,17$ & ?Devonshire Quarrenden x ? \\
\hline Yingqiu & $\mathrm{S}_{1}^{2} \mathrm{~S}_{7}^{24}$ & 11 & \\
\hline
\end{tabular}

$\mathrm{S}$-alleles in apple. On the basis of our current knowledge on the S-alleles operating in apple, we have reviewed the results of other S-allele genotyping initiatives in apple using previous or similar versions of our allele-specific PCR method (Sakurai et al., 1997, 2000; Matsumoto et al., 1999). These data were included in Table 1 whenever they reported the complete S-genotype of the cultivars assayed, i.e., both $\mathrm{S}$-alleles for a diploid cultivar and all three alleles for a triploid cultivar. Moreover, the $\mathrm{S}$-genotypes proposed on the basis of S-RNase discrimination by gel electrophoresis or on the basis of pollination studies have been compiled as well, unless the results were different from those obtained by allele-specific PCR. In every case, the corresponding references are indicated. The numbering used to identify the S-alleles follows the revised annotation (Broothaerts, 2003) and may, therefore, differ from that in earlier publications.

In Table 1, a total of 150 apple cultivars are listed with their S-genotype. This includes most cultivars commonly cultivated in various 


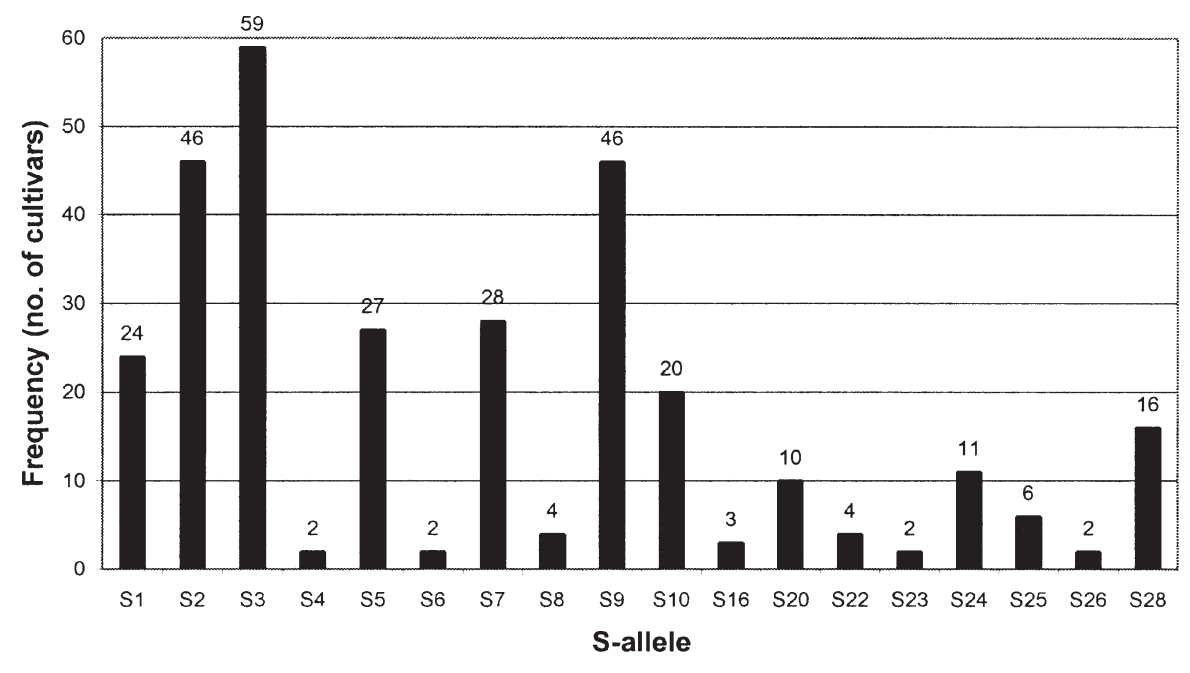

Fig. 1. Frequency of S-alleles in the 150 apple cultivars evaluated

parts of the world, as well as a number of older cultivars that were studied for their incompatibility phenotype and cultivars that have been used in breeding programs. All entries reveal both alleles of the cultivar, or all three alleles in the case of a triploid cultivar, except for three cultivars in which we found only one of the S-alleles. These cultivars are 'Ingrid Marie', 'Radoux', and Malus floribunda 821. The remaining allele is specified with a question mark $\left(S_{?}\right)$ in Table 1 , which could refer to $S_{6}$, $\mathrm{S}_{8}, \mathrm{~S}_{25}$ (not determined) or one of the alleles that is not discriminated here.

As the S-allele inheritance may be used to confirm the presumed origin of a cultivar, the parentage of the cultivars, if known, is included in Table 1. In all but five cases, the deduced $\mathrm{S}$-genotype of the cultivars corresponded with the inheritance of the S-alleles from the presumed parents of known S-genotype. The doubtful parentage of four cultivars for which the S-alleles differed from that conferred by the parents has already been reported (Boškovi and Tobutt, 1999; Sakurai et al., 2000). For 'Korei' $\left(\mathrm{S}_{3} \mathrm{~S}_{28}\right)$, the male parent should have been different from 'Indo', because 'Indo' does not have the $\mathrm{S}_{28}$-allele.

Many common cultivars are derived from a small group of successful cultivars, such as 'Golden Delicious' $\left(\mathrm{S}_{2} \mathrm{~S}_{3}\right)$, 'Delicious' $\left(\mathrm{S}_{9} \mathrm{~S}_{28}\right)$, 'Jonathan' $\left(\mathrm{S}_{7} \mathrm{~S}_{9}\right)$ and 'Cox Orange Pippin' $\left(\mathrm{S}_{5} \mathrm{~S}_{9}\right)$. It is, therefore, predicted that the $\mathrm{S}$-alleles of these donor cultivars have been preferentially introgressed in the pool of cultivars that are the result of planned breeding programs. Many new apple cultivars have resulted from chance hybridizations, however, making it difficult to distinguish between those that have one of the common parental donors in their breeding history and those that have not. Therefore, we decided to calculate the frequency of different $\mathrm{S}$-alleles among the 150 cultivars examined. The frequency distribution revealed the strong prevalence of the $S_{3}$-allele, and to a slightly lesser extent that of $\mathrm{S}_{2}$ and $\mathrm{S}_{9}$ (Fig. 1). In fact, $19 \%$ of the cultivars $(28 / 150)$ had an S-genotype composed of these three S-alleles, and at least one of these was present in 116 cultivars $(77 \%)$. On the other hand, several other alleles $\left(\mathrm{S}_{4}, \mathrm{~S}_{6}, \mathrm{~S}_{8}, \mathrm{~S}_{16}, \mathrm{~S}_{22}, \mathrm{~S}_{23}\right.$ and $\mathrm{S}_{26}$ ) were extremely rare and appeared in only four or fewer cultivars.

\section{Discussion}

Due to the inconsistent labeling of S-alleles and some erroneous data in the literature, there is confusion on the $S$-allele genotypes in apple. We present the first comprehensive overview of common apple cultivars with their S-allele genotype, based on the most recent evidence on the unique identification of the apple S-alleles. Most of the 20 major cultivars based upon their share of world production (The World Apple Report, Jan. 2002, Belrose Inc.), and many more local cultivars grown in North America, Europe, and Japan were included in the evaluation. The majority of the entries in Table 1 are domestic cultivars, along with two crabapple cultivars ('Maypole' and 'Baskatong') and $M$. floribunda. Sports of common cultivars are not listed separately, except for 'Wijcik', which is a columnar sport of 'McIntosh'. The list contains data on 137 diploid and 14 triploid cultivars, of which the S-genotypes are composed of various combinations of the $18 \mathrm{~S}$-alleles that have been unequivocally discriminated. Cultivars that have been proposed to bear one or more S-alleles differing from these 18 alleles were excluded. These excluded S-alleles, $S_{11}$ to $S_{15}$, $S_{17}$ to $S_{19}$ and $S_{21}$ were originally introduced by Boškovi and Tobutt (1999). The evidence for their discrimination is controversial (except for $\mathrm{S}_{19}$, see introduction), as only their gene products have been visualized on protein gels and they were only reported from a single cultivar (Broothaerts, 2003 and Matsumoto et al., 2003). The S-genotypes of the excluded cultivars have, however, been reported and discussed in a separate paper (Broothaerts, 2003). Also a number of cultivars that were only partly examined in the past were omitted from this compilation, except for three cultivars which were the only three cultivars from our own recent work in which the second allele was not detected. For most cultivars, the evidence for the correct S-allele assignment seems strong and is often supported by studies at the DNA and protein level, as well as by functional assessments through pollinations. The S-genotype listing presented in this paper should provide valuable information for the planning of apple breeding programs preventing incompatible crossings. Furthermore, the selection of suitable pollinizers may now more accurately include the correct compatibility relationships in addition to other factors that need to be considered, such as the overlapping of the blooming periods.

'Liberty' presents a special case, for we detected three $S$-alleles $\left(\mathrm{S}_{3} \mathrm{~S}_{5} \mathrm{~S}_{10}\right)$ for this diploid cultivar. A similar observation was earlier reported for 'Adam's Pearmain' (Broothaerts, 2003). On the basis of fluorescence microscopy evaluation of a limited number of reciprocal pollinations, 'Liberty' was found to be crossincompatible with 'Delbarestivale' $\left(\mathrm{S}_{3} \mathrm{~S}_{10}\right)$, but 'Liberty' $x$ 'Elstar' $\left(\mathrm{S}_{3} \mathrm{~S}_{5}\right)$ revealed plenty of pollen tubes near the stylar base. While these results suggest the S-genotype of 'Liberty' to be $\mathrm{S}_{3} \mathrm{~S}_{10}$, Sakurai et al. (2000) reported it to be $\mathrm{S}_{3} \mathrm{~S}_{5}$. In our pollination study, 'Liberty' produced many nonviable pollen grains and irregular pollen tubes when applied to various pistil genotypes, which suggest ploidy distortions. Moreover, several seedlings of 'Liberty' unexpectedly are triploids, in which 'Liberty' contributed the unreduced gamete (Sakurai et al., 2000 and S. Brown, personal communication). It is clear that our detection of three S-alleles in 'Liberty' (and 'Adam's Pearmain') is intriguing in light of these other observations and merits further examination in additional studies.

In total, $18 \mathrm{~S}$-alleles have been discriminated in this study. Two of them, $\mathrm{S}_{16}$ and $\mathrm{S}_{22}$, express the same functional specificity, while differing only slightly at the DNA level (Van Nerum et al., 2001). With these 18 S-alleles, the $S$-genotype of all $2 n$ and $3 n$ apple cultivars investigated could be assigned, except for three cultivars that were only partly genotyped. If these three cultivars each bore a different unknown S-allele, then the total number of S-alleles in the apple germplasm studied would be 21. Sixty diploid incompatibility groups are represented in Table 1. While theoretically it is possible to form 306 incompatibility groups out of 18 alleles, the actual number of cross-incompatible groups is already large enough to expect few incompatibility problems in natural settings or in breeding practices. There are, however, large differences in the frequency of occurrence of the S-alleles in apple cultivars. For instance, there is almost a 30-fold difference in frequency between the most frevalent allele $\left(\mathrm{S}_{3}\right)$ and the four most rare alleles. Furthermore, 131 of the 150 entries $(87 \%)$ are fully genotyped with only 11 of the $18 \mathrm{~S}$-alleles. The remaining seven alleles were found in less than 5 of the 150 cultivars, and five of them, $\mathrm{S}_{4}, \mathrm{~S}_{6}, \mathrm{~S}_{16}, \mathrm{~S}_{23}$ and $\mathrm{S}_{26}$, occurred only twice. Some of these rare alleles have been detected in other old or noncommercial cultivars (Broothaerts, 2003).

Although it has not been our objective to provide an unbiased or random sample of cultivars, the wide distribution of the $\mathrm{S}_{3}$-allele in particular is striking. The high frequency of the 
$\mathrm{S}_{3}$-allele is attributed mainly to the widespread use of 'Golden Delicious' $\left(\mathrm{S}_{2} \mathrm{~S}_{3}\right)$ and its derivatives in many breeding programs in the past and present. However, among the cultivars in Table 1 that are derived from 'Golden Delicious', the inheritance of the $\mathrm{S}_{2}$-allele was similar to that of the $S_{3}$-allele (14 and 13 cultivars, respectively). The dominance of the 'Golden Delicious' S-alleles in breeding programs is further exemplified by the presence of either of its S-alleles in all of the scab-resistant cultivars evaluated (Table 1). M. floribunda 821 has been widely employed as a source of scab resistance ( $V f$ gene) in the breeding of such cultivars. It is striking that none of the ten scab resistant cultivars studied introgressed either of the $\mathrm{S}$-alleles from its scab resistant parent. As the introgression of the resistance from $M$. floribunda into a commercial cultivar requires several generations, we can assume that a large part of the crabapple background, including its S-locus, was removed through breeding. It would be interesting to investigate more carefully whether the widespread presence of some of the S-haplotypes has affected some of the attributes of modern apple cultivars.

\section{Literature Cited}

Boškovi , R. and K.R. Tobutt. 1999. Correlation of stylar ribonuclease isoenzymes with incompatibility alleles in apple. Euphytica 107:29-43.

Broothaerts, W., G.A. Janssens, P. Proost, and W.F.
Broekaert. 1995. cDNA cloning and molecular analysis of two self-incompatibility alleles from apple. Plant Mol. Biol. 27:499-511.

Broothaerts, W. 2003. New findings in apple Sgenotype analysis resolve previous confusion and request the re-numbering of some $\mathrm{S}$-alleles. Theor. Appl. Genet. 106:703-714.

Golz, J.F., H.-Y. Oh, V. Su, M. Kusaba, and E. Newbigin. 2001. Genetic analysis of Nicotiana pollen-part mutants is consistent with the presence of an S-ribonuclease inhibitor at the S-locus. Proc. Natl. Acad. Sci. USA 98:15372-15376.

Janssens, G.A., I.J. Goderis, W.F. Broekaert, and W. Broothaerts. 1995. A molecular method for S-allele identification in apple based on allele-specific PCR. Theor. Appl. Genet. 91:691-698.

Kitahara, K., J. Soejima, H. Komatsu, H. Fukui, and S. Matsumoto. 2000. Complete sequences of the $\mathrm{S}$-genes 'Sd-' and 'Sh-RNase' cDNA in apple. HortScience 35:712-715.

Kitahara, K. and S. Matsumoto. 2002. Sequence of the $\mathrm{S}_{10}$ cDNA from 'McIntosh' apple and a PCR-digestion identification method. HortScience 37:187-190.

Kobel, F., P. Steinegger, and J. Anliker. 1939 Weitere Untersuchungen über die Befruchtungsverhältnisse der Apfel- und Birnsorten. Landw. Jb. Schweiz 53:160-191.

Komori, S., J. Soejima, K. Abe, N. Kotoda, and H. Kato. 2000. Analysis of S-allele genotypes and genetic diversity in the apple. Acta Hort. 538:83-86.

Matsumoto, S., K. Kitahara, S. Komori, and J. Soejima. 1999. A new S-allele in apple, 'Sg', and its similarity to the 'Sf' allele from 'Fuji'.
HortScience 34:708-710.

Matsumoto, S. and K. Kitahara. 2000. Discovery of a new self-incompatibility allele in apple. HortScience 35:1329-1332.

Matsumoto, S., K. Kitahara, Y. Furusawa, H. Komatsu, J. Soejima, and H. Fukui. 2003. S-allele genotype of apple cultivars and selections. Acta Hort. (in press)

Sakurai, K., S.K. Brown, and N.F. Weeden. 1997. Determining the self-incompatibility alleles of Japanese apple cultivars. HortScience 32:1258-1259.

Sakurai, K., S.K. Brown, and N.F. Weeden. 2000. Self-incompatibility alleles of apple cultivars and advanced selections. HortScience 35:116-119.

Sassa, H., N. Mase, H. Hirano, and H. Ikehashi. 1994. Identification of self-incompatibility-related glycoproteins in styles of apple (Malus $\times$ domestica). Theor. Appl. Genet. 89:201-205.

Sassa, H., T. Nishio, Y. Kowyama, T. Hirano, T. Koba, and H. Ikehashi. 1996. Self-incompatibility $(S)$ alleles of the Rosaceae encode members of a distinct class of the $\mathrm{T}_{2} / \mathrm{S}$ ribonuclease superfamily. Mol. Gen. Genet. 250:547-557.

Van Nerum, I., M. Geerts, A. Van Haute, J. Keulemans, and W. Broothaerts. 2001. Re-examination of the self-incompatibility genotype of apple cultivars containing putative 'new' S-alleles. Theor. Appl. Genet. 103:584-591.

Verdoodt, L., A. Van Haute, I.J. Goderis, K. De Witte, J. Keulemans, and W. Broothaerts. 1998. Use of the multi-allelic self-incompatibility gene in apple to assess homozygocity in shoots obtained through haploid induction. Theor. Appl. Genet. 96:294-300. 